\title{
BUSINESS MODEL AS A VALUE MANAGEMENT TOOL
}

\author{
Viktoriia Kyfyak' ${ }^{\text {, Andrii Antokhov², Serhii Todoriuk }}{ }^{3}$
}

\begin{abstract}
Urgency of the research. In the crisis conditions of quarantine, business modelling has become the subject of scientific debate and demand from businesses. Applying conservative approaches to business models has caused significant financial losses and depreciation of business value. Thus, value models that reflect the assessment of various business processes in monetary terms are becoming especially relevant. Therefore, managers understand the synergetic effect of the procedural approach to business processes construction and the component contribution of business processes in achieving the goals of the enterprise. The research purpose is the improving of the scientific principles and development of a methodical approach to improvement of scientific bases and the formation of a business model from a value point of view, which has practical significance for the formation of a vision of business development. Uninvestigated parts of general matters defining. In the conditions of social crisis and fluctuations, many tools of business development and its business modelling have lost their relevance. Businesses need to find the latest approaches to business structuring and development. Research methodology. The basis of the study is a systematic analysis and a comprehensive approach to the formation of methods for building a cost-effective business model of the enterprise. Analysis and synthesis were used to characterize approaches to business modelling and determine their features, and the dialectical method was used to formulate the essence of the category "business model". Using statistical methods allowed to get trends in the business and its modelling analysed. For a complex representation of the model, a graphical method was used (for visualization of the model) and economic mathematical modelling for the representation of the model, which has practical significance in the trends of digitalization of business processes. Results. The article substantiates that the formation of a value business model is a prerequisite for a radical rethinking of business approaches, creating the potential for its development and a starting point for innovation and change. After analysing different approaches to business modelling and to estimating the value of business on the basis of a systematic approach, a value business model is proposed, which consists of a value rhombus and a square of potential. This model includes all business processes of the enterprise and assesses the potential of business development. Practical implications. The business model and clear well-defined mechanisms of its formation are a necessary requisition for business development. Scientists are often inclined to think that a business model is a complex mathematical or econometric expression. However, in practice, it is the graphic visualization of the business structure that is important in terms of forming a deep understanding of business as a system and areas for improving its components. Value/originality. The proposed approach to business modelling can be used in the following areas: evaluation of business efficiency as an individual enterprise, and in comparison as well; assessment of investment attractiveness of the business; assessment of business potential and directions of its development; analysis of the market potential of the enterprise; strategic analysis of business development and determination of its competitive advantage; a basis for the software or systems of the Workflow class development.
\end{abstract}

Key words: business model, valuation, development potential, business development, system approach.

JEL Classification: M21, C18, L22, O21, C02

\footnotetext{
Corresponding author:

${ }^{1}$ Yuriy Fedkovych Chernivtsi National University, Ukraine.

E-mail:V.Kyfyak@chnu.edu.ua

ORCID: https://orcid.org/0000-0002-6104-6403

ResearcherID: D-3608-2016

${ }^{2}$ Yuriy Fedkovych Chernivtsi National University, Ukraine.

E-mail: a.antochov@chnu.edu.ua

ORCID: https://orcid.org/0000-0003-3887-9666

ResearcherID: D-1664-2016

${ }^{3}$ Yuriy Fedkovych Chernivtsi National University, Ukraine.

E-mail: s.todoriuk@chnu.edu.ua

ORCID: https://orcid.org/0000-0003-4399-5952

ResearcherID: C-6830-2016
} 


\section{Introduction}

Uncertainty and new social challenges require business structures to seek and apply the latest management approaches. To maintain a competitive position, most businesses implement innovative tools that have proven their effectiveness in the business. In modern conditions, such tools that are effective in conditions of fluctuations have become a process approach, digitalization and flexible forms of management. In order to maintain profitable positions, entrepreneurs must form a new business model based on a comprehensive approach to internal and external factors. The approach to business valuation, which takes into account both the financial and economic results and the ability of the enterprise as a system to operate in conditions of fluctuations, also needs to be reconsidered.

Most studies focus on the modernization of business processes of the enterprise, delaying the core business - the business model. As practice shows, most business structures that operate without being aware of the business model and not paying enough attention to setting up a business system, do not occupy a leading position in the market and their profitability is unstable. Conversely, companies that focus on system connections, mission definition, and business structure make a profit and are market leaders.

Due to the growing level of uncertainty, the business modelling process has become much more complicated, and the business value dynamics analysis has become an important component of management. The enterprise management system in crisis conditions should be based on cost approaches to management decisions. A sound business model is a tool for research and business development at the same time. Underestimation of the validity of business models has led such companies as Nokia, Motorola, Kodak, Lehman Brothers, etc. to the crisis. And the constant focus on the effective construction of business processes based on cost management, aimed at increasing the value of the business offer is the key to the success of all well-known companies that operate today.

Therefore, the formation of a business model based on a systems approach is an applied tool for achieving goals by business structures. And in the fluctuating conditions of management, the developed business model is a competitive position holding tool, which is relevant for enterprises in modern conditions.

\section{Analysis of recent research and publications}

In times of crisis caused by quarantine, business modelling has become the subject of scientific debates and business structures demand.

Today, the business model is a central link in business fashion trends such as digitalization, business engineering and reengineering. The increase in interest is due to both the changes that have taken place in society due to quarantine restrictions, and the development of a systematic approach in scientific circles and in practice.

Scientists study the business model from different perspectives, for example:

- conceptual aspects of business modelling (Maucuer, Renaud, 2019; Stephan von Delft, Yang Zhao, 2020);

- business model as a tool for doing business (BadenFuller C., Mangematin V., 2013), and a strategic vision of the business model (Casadesus-Masanell, Enric Ricart, 2010);

- business model as a description of the organization and analysis of its activities (George, Bock, 2011; Johnson, Christensen, Kagermann, 2008);

- business model as a starting point of business engineering, reengineering and transformations (Nelson, Winter, 1982; Schneider, Spieth, 2014).

- business model in terms of creating business value (Zott, Amit, 2007; Costa Climent, Darek M. Haftor, 2021).

The Canvas business model (Osterwalder, Pigneur, 2013) is the most popular today. It is characterized by clear visual representation and ease of understanding. STOF, CSOFT, VISOR models are also well-known and used in practice. Their distinguishing feature is a procedural approach to business modelling. In the STOF model (Bouwman H., de Vos H., Haaker T., 2008), the object of study is the service provided by the enterprise. The model includes such components as supply cost, service, technology, organizational structure and financial component.

The CSOFT business model (Heikkilä, Tyrväinen, Heikkilä, 2010) is based on the analysis of customers, service, organizational structure, technology and finance. This methodological approach evaluates alternative business models within one business structure.

The main components of the VISOR business model (Pateli, Giaglis, 2004) are business elements that include an innovative approach and flexibility of solutions (cost proposition, interfaces, service platforms, organization model and revenue model).

The article is based on the hypothesis that the purpose of any activity and transformation (including modelling) is to increase and maximize the growth of the value of the enterprise. Thus, Copeland T., Koller T., Murrin J. (2000) argue that the main task of managers is to manage value through the evaluation of business components. Arnold G. (1998) defines the elemental structure of the concept of value management. Skott M. (2005) offers a method for determining the main components of value. Damodaran A. (2012) identifies the relevance and practical approaches to valuing companies. 
However, there are a number of studies of sustainable development modelling of the enterprise (a combination of economic, social and environmental components of business). In the context of sustainable development, which is a necessary prerequisite for the enterprises functioning, business model constructing is made by (Abdelkafi, Täuscher, 2016; Boocken, NMP, Rana, Short, 2015; Boons, Laasch, 2019; Lüdeke-Freund, Rauter, Pedersen, Nielsen, 2020).

Modern literature reviews should include the development of companies for business modelling, such as Deloitte and PWC. The business model is seen as a way to structure business processes.

In the conditions of social crisis and fluctuations, many tools of business development and its business modelling have lost their relevance. Enterprises need to find the latest approaches to business structuring and development.

The purpose of the study is to improve the scientific basis and develop a methodological approach to the formation of a business model in terms of value, which is of practical importance for the formation of a vision of business development.

\section{Research methodology}

The basis of the study is a systematic analysis and a comprehensive approach to the formation of methods for building a cost-effective business model of the enterprise. Analysis and synthesis were used to characterize approaches to business modelling and determine their features, and the dialectical method was used to formulate the essence of the category "business model". Using statistical methods allowed to get trends in the business and its modelling analysed.

For a complex representation of the model, a graphical method (for visualization of the model) and economic mathematical modelling for the representation of the model, which has practical significance in the trends of digitalization of business processes, were used.

\section{Materials and methods}

Rapid changes in consumer demand and the development of competitors necessitate the consideration in the business model of long-term forecasts of the status and market conditions and resource opportunities of the business, its qualitative and quantitative parameters. A reasonable assessment of the business will provide an opportunity to establish effective communication with partners, investors and other counterparties, to form a competitive advantage of the business and consumer value.

In a crisis, synthetic models that combined different methods of business management and evaluation were particularly effective. The flexibility of business management as a competitive advantage in the crisis was especially acute. Applying conservative approaches to business models has caused significant financial losses and depreciation of business value. Thus, cost models that reflect the assessment of various business processes in monetary terms are becoming especially relevant. Therefore, managers understand the synergetic effect of the procedural approach to business processes construction and the component contribution of business processes in achieving the goals of the enterprise.

According to the resource Practical Ecommerce (Armando, 2014), 8 out of 10 online stores cease operations. At the top of the main reasons there is the lack of strategy, vision or competence. That is, a business model and clear precise mechanisms for its formation are a necessary condition for business development.

Business model development is a conceptual description of the enterprise's activity and its value. It is a constant process of measuring resource, labour and social capital. That is, this process involves two stages: model formation and adjustment.

In business modelling, a methodical approach, consistency and understanding of basic analytical methods are important. What is really difficult is to find effective ways to present abstract concepts on paper, such as data flows, metrics, the sequence of operations in processes and the relationship between.

Researchers are often inclined to think that a business model is a complex mathematical or econometric expression. However, in practice, it is the graphic visualization of the business structure that is important in terms of forming a deep understanding of business as a system and areas for improving its components.

The formation of a business model in terms of valuation has a number of features:

- the monetary dimension of the business reflects the potential for development;

- valuation of business processes shows which of them are the most important and how to develop it;

- this model shows the value of relationships,

- assessment of the value of the business on the proposed components allows you to structure the data in electronic format (for example, in Excel and 1C);

- forms the investment attractiveness of the business.

There are two approaches to assessing the value of a business: procedural and functional.

The founder of the process approach is M. Hammer and J. Champy (1993), who described the construction of business processes focused on the consumer (the external aspect of the enterprise). Therefore, the value of a business is largely assessed by the extent to which the business structure meets consumer demands and takes into account the market potential of its development. Such models emphasize the creation of entrepreneurial value for consumers. 
The functional approach focuses on the analysis of the internal structure and cost of technologies and resources. Here the schemes of increase of value of the enterprise are considered.

Based on this, most definitions of the term "business model" can be divided into two categories focused on:

1. Market value for consumers and partners namely focused on the environment. According to this approach, a business model is an idea of how an enterprise makes (or intends to make) money. The business model describes the value that the company offers to different customers, reflects its competencies, the list of partners needed to create, promote and supply this value to customers, the capital ratio needed to obtain sustainable income flows.

2. Resource potential - assessment of internal resources and capabilities, namely focused on the internal environment.

The first approach corresponds to the procedural model of building business processes, the basis of which is the focus on consumers and the formation of consumer value of products in each business process.

The second is a systems design approach, according to which the enterprise is a set of elements in the interaction, communication and structure of which are the object of modelling.

From the above approaches to the business model, it can be seen that the set of features that make up the meaning of this term can be quite wide. At the same time, all researchers identify the key elements of the business model that are specific to any enterprise and determine its main content (Soolyatte, 2010):

- value for external customers, which the company offers on the basis of its products and services;

- a system of creating this value, which includes suppliers and target customers, as well as value chains;

- assets that the company uses to create value;

- financial model of the enterprise, which determines the structure of its costs and ways to make a profit. We believe that it is worth using a comprehensive approach that includes both the value of the enterprise and its consumer value.

According to the orientation of time assessment, a distinction is made between the actual value of the business and the potential. Actual determines the total value of the business: capital, resources and assets. This methodological approach is traditional.

Potential assessment includes the cost of development and development potential. Despite the importance of these characteristics, these components are not evaluated in practice in terms of value, only on an intuitive level and oral justification. But an integrated approach should include both its real value and business prospects (market potential). We propose to combine all types of approaches to the business valuation model on the basis of systematic and integrated approaches, that is to take into account the resource potential and market value, the actual state and prospects of business development. However, in reality, business models are important only in the case of increasing financial results and achieving a significant economic effect.

According to our methodology, in addition to the complexity and comprehensive assessment of business processes, the result of business modelling should be an assessment of the business and its components value.

The scheme of complex assessment of the enterprise is shown in Figure 1, which shows two components of business value: a value rhombus and a square of potential. The value rhombus reflects the components that have the traditional value expression: intangible assets, capital, profit, and income. The square of potential reflects the basis of business development, i.e., it is a kind of addition to the classic components of value.

An integrated approach to business modelling can be used as a tool for the following purposes:

1. Evaluation of business efficiency as an individual enterprise, and in comparison.

2. Assessment of investment attractiveness of the business.

3. Assessment of business potential and directions of its development.

4. Analysis of the market potential of the enterprise.

5. Strategic analysis of business development and determination of its competitive advantage.

6. Market value and the system of formation of this value.

Let us define a way of cost expression of components of the offered business model by mathematical tools and advanced techniques.

\section{Cost expression of business model components}

After analysing the different approaches to the valuation of the components of the model, we propose to apply the following:

The value of intangible assets. The accumulation of intangible assets is a steadily growing function that has an autoregressive character. In particular, the determining factors of this process are the current values of assets, the volume of attracted investments and their shocks, return on investment and the amount of depreciation of intangible assets. Under such conditions, the market value of assets can be expressed as follows:

$$
A_{t+1}=a\left(\beta I_{t}\right)+(1-\theta) A_{t}
$$

where $A_{t+1}$ is the amount of accumulated intangible assets for the next period; $\alpha$ is a return on investment coefficient; $I_{t}$ is volume of investments; $\theta$ is an asset depreciation ratio. 


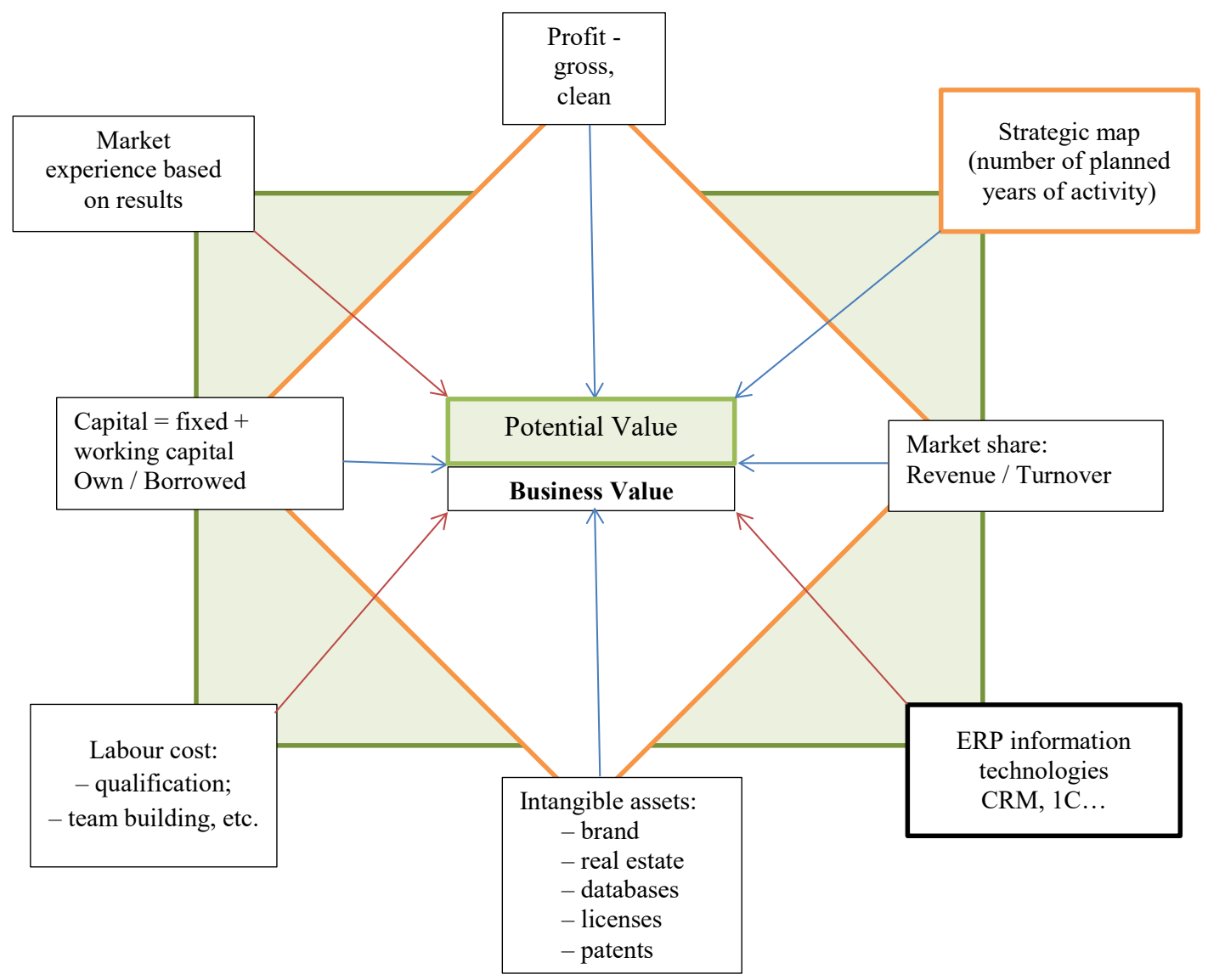

Figure 1. Business valuation

The labour costs. From the point of view of the process approach, the labour cost is assessed as a synergistic result of the interaction of members of the workforce. Therefore, the model of labour costs will be analysed from the standpoint of team building, taking into account interpersonal relationships in the organization, based on research (Dotsenko, Sabadosh, Chumachenko, 2015).

$\left\{P=P_{1}, P_{2}, \ldots . P_{n}\right\}$ is a quantity of applicants.

Next, consider a set of functional units, whose employees meet the criteria of this project.

$\left\{F=F_{1}, F_{2}, \ldots . F_{m}\right\}$ is a set of functional departments.

Let us make the target function of the staff (business team):

$$
F=\sum_{j=1}^{k} V(P j) \rightarrow \max _{p j=p}
$$

where $V(P j)$ is the applicant's $P j$ contribution in group interaction, $\mathrm{k}$ is the total number of employees to be involved in the project.

$$
\begin{aligned}
& S_{j}=\{s \mid s \in P\}, j=\overline{1, m ;} \\
& U_{j=1}^{m} s_{j}=P ; n_{j=1}^{m}=0
\end{aligned}
$$

where $s_{j}$ is the set of candidates represented by one department.
The cost of capital will be considered from a systemic point of view, where a necessary aspect in the formation of a business model will be taking into account the factors influencing the capital structure. The econometric linear model of capital structure can be represented in the following general form (Hurnak, Pryimenko, 2007):

$$
K_{i}=a_{1} x_{1 i}+a_{2} x_{2 i}+\ldots+a_{n} x_{n 1}+\omega_{i}
$$

where $a_{1}, a_{2}, \ldots a_{n}$ is a capital structure of the enterprise at time 1 (dependent variable);

$x_{11}, x_{21}, \ldots, x_{n 1}$ is a set of factors influencing the capital structure of the enterprise at time 1 (explanatory variables);

$a_{1}, a_{2}, \ldots ., a_{n}$ are parameters of the regression of the capital structure;

$\omega_{i}$ is a stochastic component of the model, respectively.

The coefficient of concentration of loan capital $\left(\omega_{i}\right)$ was used to quantify the dependent variable (capital structure of the enterprise). This indicator reflects the share of loan capital in the total amount of capital used by the enterprise. The selection of factors influencing the capital structure was carried out on the basis of generalization of existing theories of capital structure and practical activities of domestic industrial enterprises (Table 1). 
Vol. 7 No. 2, 2021

Table 1

Factors influencing the enterprise capital structure

\begin{tabular}{|c|c|c|c|c|}
\hline № & Factor & Indicator & Alternant in the model & $\begin{array}{c}\text { Expected relationship with the } \\
\text { dependent alternant (U) }\end{array}$ \\
\hline 1 & Profit variability & $\begin{array}{c}\text { The standard deviation of the company's } \\
\text { net profit per hryvnia of assets }\end{array}$ & X11 & Negative \\
\hline 2 & The efficiency of the enterprise & Return on assets of the enterprise & X21 & Negative \\
\hline 3 & The size of the enterprise & The value of the assets of the enterprise & X31 & Positive \\
\hline 4 & $\begin{array}{c}\text { Dynamics of enterprise assets } \\
\text { The growth rate of the company's assets } \\
\text { compared to the previous period }\end{array}$ & X41 \\
\hline 5 & $\begin{array}{c}\text { The structure of enterprise } \\
\text { assets }\end{array}$ & $\begin{array}{c}\text { The share of tangible non-current assets } \\
\text { in the total assets of the enterprise }\end{array}$ & X51 & Positive \\
\hline 6 & $\begin{array}{c}\text { Management's position } \\
\text { on the use of loan capital }\end{array}$ & $\begin{array}{c}\text { The share of bank loans in the loan } \\
\text { capital of the enterprise }\end{array}$ & X61 & Positive \\
\hline 7 & Tax factor & The ratio of income tax to net income & X71 & Negative \\
\hline
\end{tabular}

Source: (Hurnak, Pryimenko, 2007)

Market experience. Most approaches to business valuation do not take into account such a component as market experience. We believe that this element is important because it determines the competitiveness of the enterprise, qualifications and dedication of staff, image, etc. Of course, the effectiveness of the years in which the company operated is important. But, of course, this experience should be taken into account in the business model. The value of market experience is estimated as the number of years multiplied by the discounted profitability of the enterprise in those years.

$$
V=P r * N k
$$

where $P r$ is the annual net income (profit);

$N k$ is the capitalization rate.

Market share can be considered through the design of future cash flows. The current economic situation and prospects of the enterprise are taken into account when determining the discount rate. Methods of discounting future cash flows (net profit flows, dividend payments)

$$
V=\sum_{n=1}^{N} C F_{n} \frac{1}{(1+r)^{n}}+V
$$

where $V$ is the book value of the company;

$C F$ is cash flows (net profit, dividend payments) of the company for one time interval;

$r$ is discount rate;

$V z$ is the residual value of the company in the postforecast period;

$N$ is the quantity of time intervals;

$n$ is the number of the time interval.

The advantages of this technique are the ability to estimate the company's revenues in the near future. And the main limiting factor is the difficulty of determining the discount rate and the factors that will determine it.

The company's profit is estimated by the method of EVA [1]:

$$
E V A=E B I T(1-T)-W A C C
$$

where EVA is an economic value added;
$E B I T$ is the earnings before interest and taxes;

$C$ is the amount of capital;

$T$ is income tax rate;

WACC is weighted average cost of capital.

The indicator of profit before taxes and interest is taken from the "Statement of financial performance". The amount of capital is reflected in the liabilities of the balance sheet (it includes own and borrowed funds). The income tax rate today is 25 percent. The weighted average cost of capital is the average cost of equity and debt capital, weighted by their shares in the overall capital structure (Martin J., Petty J., Wallace, J., 2009):

$$
W A C C=W_{d} C_{d}(1-T)+W_{p} C_{p}+W_{e} C_{e}
$$

where $W d, W p$, We are the share of borrowed funds, preferred shares, equity (ordinary shares and retained earnings) respectively;

$C d, C p, C e$ are the value of each of the relevant parts of the capital;

$T$ is income tax rate.

Strategic map. A business model is often identified with a strategy, mistakenly substituting one category for another, or including strategy as one of the components of a business model. This is because the business model is closely linked to strategy. This relationship between the business model and strategy can be illustrated by the "value equation" proposed by M. Levy (Laudon K. C., Traver C. G., 2003):

$$
V=M * S \text {, }
$$

where $V$ is a value;

$M$ is a model (a business model);

$S$ is a strategy.

In the model we offer a valuation of the strategic map to be calculated as the number of planned years of activity multiplied by the discounted profitability of the enterprise for the future planned period.

The level of business innovation. The value of the business must take into account, on the one hand, the 
level of innovation, and the degree of technological structure, on the other hand.

$$
A=\text { Innov }_{t}+T_{t} \text {, }
$$

where Innov $v_{t}$ is the level of innovation of the economy; $T_{t}$ is the degree of technological structure.

Information technology as a value for the company is reflected in the following mathematical expression:

$$
I=f(I)-(1+p) B_{f}+(1+h r) \mathrm{L}^{\mathrm{r}}
$$

where $f(I)$ is the information function of the firm, which determines the volume of its sales depending on the amount of promotion costs.

$p$ is the rate of regular maintenance costs of CRMsystems;

$B_{f}$ is the cost of CRM-system of the enterprise;

$h r$ is additional economic benefits from the implementation of CRM-systems are related to personnel management and speed of execution of decisions;

$L$ is value expression of the working time of employees.

Such tools allow to use software to calculate the component structure of the value of the enterprise and construct its cost model.

And effective modelling is the basis for designing innovations, implementing new approaches or applying other changes to improve business processes or business structure.

Competent business modelling can change the business culture and process management in the company. As a result, the process model becomes a live, relevant and real part of the business and daily activities of the organization (Bouwman H., de Vos H., Haaker T., 2008).

\section{Conclusions}

As a result of the study we came to the following conclusions:

1. The formation of a cost-effective business model is a prerequisite for a radical rethinking of business approaches, it creates the potential for its development and a starting point for innovation and change.

2. After analysing different approaches to business modelling and to estimating the value of business on the basis of a systematic approach, a cost business model is proposed, which consists of a value rhombus and a square of potential. This model includes all business processes of the enterprise and assesses the potential of business development.

3. The mathematical expression of model components which correspond to the process approach and cost estimation and can serve as the tool of formation of a software product is offered.

4. The use of such a methodological approach to business modelling creates the following advantages:

- a holistic vision of the business as a whole and its structure is formed;

- a comprehensive database system about business, its development and necessary changes is created;

- use of different types of approaches to modelling: graphic (visual), mathematical and software approach.

- is the basis for the development of software or systems of the Workflow class;

- the chain of causal relations is traced;

- such a model forms an understanding of the value of business processes and their relationships;

- the model allows to calculate and analyse a number of indicators of economic efficiency of business;

- the model allows to analyse the competitive advantages of the business;

- the model identifies contradictions and shortcomings of the business structure.

Prospects for further researches should be the application of the proposed business model using specialized software, understanding of which requires professional featured knowledge. In addition, the model can be modified depending on the areas and types of the activity.

\section{References:}

Osterwalder, A., \& Pigneur, Y. (2013). Postroenie biznes-modelei. Nastolnaia kniga stratega $i$ novatora [Building business models. Handbook of the strategist and innovator]. Skolkovo: Alpina Publisher. (in Russian)

Bouwman, H., de Vos H., \& Haaker, T. (2008). Mobile Service Innovation and Business Models. Berlin, 455 p.

Heikkilä, J., Tyrväinen, P., \& Heikkilä, M. (2010). Designing for performance - a technique for business model estimation. Research Forum to Understand Business in Knowledge Society. Tampere, p. 788.

Pateli, A. G., \& Giaglis, G. M. (2004). A research framework for analysing eBusiness models. European Journal of Information Systems, vol. 13, no. 4, pp. 302-314.

Maucuer, R., \& Renaud, A. (2019). Business Model Research: A Bibliometric Analysis of Origins and Trends. Management, vol. 2(2), pp. 176-215. Available at: https://doi.org/10.3917/mana.222.0176 (accessed 25 February 2021).

Hurnak, O. V., \& Pryimenko, T. V. (2007). Modeliuvannia optymalnoi struktury kapitalu promyslovykh pidpryiemstv [Modelling of the optimal capital structure of industrial enterprises]. Economic Donbass Bulletin, vol. 2, pp. 122-12.

Yermolenko, N. (2004). Shist krokiv do efektyvnoho upravlinnia kapitalom [Six steps to effective capital management]. Round Table, vol. 1-2 (14-15), pp. 19-21. 
Martin, J., Petty, J., \& Wallace, J. (2009). Value-Based Management with Corporate Social Responsibility: Oxford University Press. Available at: https://oxford.universitypressscholarship.com/view/10.1093/acprof: oso/9780195340389.001.0001/acprof-9780195340389 (accessed 23 February 2021).

Stephan von Delft, \& Yang Zhao (2020). Business models in process industries: Emerging trends and future research, Technovation, p. 102195. Available at: https://doi.org/10.1016/j.technovation.2020.102195 (accessed 23 February 2021).

Baden-Fuller, C., \& Mangematin, V. (2013). Business models: A challenging agenda. Strategic Organization, vol. 11(4), pp. 418-427. https://doi.org/10.1177/1476127013510112 (accessed 23 February 2021).

Casadesus-Masanell, R., \& Enric Ricart, J. (2010). From Strategy to Business Models and onto Tactics. Long Range Planning, vol. 43, issues 2-3, pp. 195-215. Available at: https://doi.org/10.1016/j.lrp.2010.01.004 (accessed 23 February 2021).

George, G., \& Bock, A. J. (2011). The Business Model in Practice and its Implications for Entrepreneurship Research. Entrepreneurship: Theory and Practice, vol. 35(1), pp. 83-111.

Johnson, M. W., Christensen, C. M., \& Kagermann, H. (2008). Reinventing Your Business Model. Harvard Business Review, vol. 86(12), pp. 50-59.

Nelson, R. R., \& Winter, S. G. (1982). An Evolutionary Theory of Economic Change, Cambridge, MA: Belknap Press, Harvard University Press.

Schneider, S., \& Spieth, P. (2014). Business Model Innovation and Strategic Flexibility: Insights from an Experimental Research Design. International Journal of Innovation Management, vol. 18(6), pp. 1-21.

Zott, C., \& Amit, R. (2007). Business model design and the performance of entrepreneurial firms. Organization Science, vol. 18, no. 2, pp. 181-199.

Abdelkafi, N., \& Täuscher, K. (2016). Business Models for Sustainability From a System Dynamics Perspective. Organization \& Environment, vol. 29, no. 1, pp. 74-96.

Boocken, N. M. P., Rana, P., \& Short, S. W. (2015). Value mapping for sustainable business thinking. Journal of Industrial and Production Engineering, vol. 32, no. 1, pp. 67-81.

Boons, F., \& Laasch, O. (2019). Business Models for Sustainable Development: A Process Perspective. Journal of Business Models, vol. 7, no. 1, pp. 9-12.

Lüdeke-Freund, Rauter, Pedersen, Nielsen (2020). Sustainable Value Creation Through Business Models: The What, the Who and the How. Journal of Business Models, vol. 8, no. 3, pp. 62-90. Available at: https://journals.aau.dk/index.php/JOBM/article/view/6510/5655 (accessed 23 February 2021).

Official site Deloitte. Available at: https://www2.deloitte.com/ua/uk/pages/strategy/solutions/business-modeltransformation-offerings.html (accessed 23 February 2021).

Official site PWC. Available at: https://www.pwc.com/ua/uk/services/deals/corporate-finance/businessmodelling.html (accessed 23 February 2021).

Hammer, M., \& Champy, J. (1993). Reengineering the Corporation: A Manifesto for Business Revolution. Nicholas Brealey Publishing, p. 223.

Laudon, K. C., \& Traver, C. G. (2003). E-Commerce: Business, Technology, Society. Addison Wesley, p. 61.

Costa Climent R., \& Darek M. Haftor (2021). Value creation through the evolution of business model themes. Journal of Business Research, vol. 122, pp. 353-361. Available at: https://doi.org/10.1016/j.jbusres.2020.09.007 (accessed 23 February 2021).

Dotsenko, N. V., Sabadosh, L. Yu., \& Chumachenko, I. V. (2015). Metody upravlinnja ljudsjkymy resursamy pry formuvanni komand muljtyproektiv ta proghram: monoghrafija [Methods of human resources management in the formation of teams of multiprojects and programs]: a monograph. Kharkiv. Nats. un-t misk. hosp-va im. O. M. Beketova, 201 p. (in Ukrainian)

Copeland, T., Koller, T., \& Murrin, J. (2000). Valuation measuring and managing the value of companies. John Wiley Sons, New York, 126 p.

Arnold, G. (1998). Corporate financial management. London: Pitman Publishing, 1050 p.

Skott, M. (2005). Faktory stoimosti: rukovodstvo dlia menedzherov po vyiavleniiu rychagov sozdaniia stoimosti [Value Factors: A Managers' Guide to Identifying Value Levers]; per. s angl. pod red. Yu. N. Ivanova. Moscow: Olimp-Bizness, $432 \mathrm{p}$.

Damodaran, A. (2012). Investment Valuation: Tools and Techniques for Determining the Value of Any Asset, 3rd ed. Wiley, 992 p. Available at: http://dspace.lzuu.lt/bitstream/1/1912/1/Investment\%20valuation.pdf (accessed 27 February 2021).

Armando, R. (2014). 8 Reasons Why Ecommerce Businesses Fail. Management and finance, vol. 7. Available at: https://www.practicalecommerce.com/8-Reasons-Why-Ecommerce-Businesses-Fail (accessed 27 February 2021).

Soolyatte, A. Yu. (2010). Biznes-model - kliuch k razvitiiu biznesa na osnove innovatcii. [The business model is the key to business development based on innovation]. Innovation management, no. 1, pp. 6-15. 